\title{
Identification of SNPs in TG and EDG1 genes and their relationships with carcass traits in Korean cattle (Hanwoo)
}

\author{
Muhammad Cahyadi ${ }^{1,2}$, Dyah Maharani ${ }^{1,3}$, Seung Heui Ryoo ${ }^{4}$, Seung Hwan Lee ${ }^{5}$, Jun Heon Lee ${ }^{1 *}$ \\ ${ }^{1}$ Department of Animal Science and Biotechnology, College of Agriculture and Life Sciences, Chungnam National University, Daejeon 305-764, Korea \\ ${ }^{2}$ Department of Animal Science, Faculty of Agriculture, Sebelas Maret University, Surakarta 57126, Indonesia \\ ${ }^{3}$ Faculty of Animal Science, Gadjah Mada University, Yogyakarta 55281, Indonesia \\ ${ }^{4}$ Livestock Research Institute, Government of Chungcheongnam-Do, Cheongyang 345-811, Korea \\ ${ }^{5}$ Hanwoo Experiment Station, National Institute of Animal Science, RDA, Pyeongchang 232-956, Korea
}

\section{한우에서 TG와 EDG1 유전자의 단일염기다형 획인 및 도체형질과의 연관성 분석}

\author{
카야디 ${ }^{1,2} \cdot$ 디아 마하라니 ${ }^{1,3} \cdot$ 유승희 ${ }^{4} \cdot$ 이승환 ${ }^{5} \cdot$ 이준헌 $^{1}$ \\ '충남대학교 농업생명과학대학 동물자원생명과학과, ${ }^{2}$ 인도네시아 세베라스마레 대학교 축산학과, ${ }^{3}$ 인도네시아 가자마다 대학교 축산대학, \\ ${ }^{4}$ 충청남도 축산기술연구소, ${ }^{5}$ 축산과학원 한우시험장
}

Received on 31 July 2012, revised on 11 September 2012, accepted on 12 September 2012

\begin{abstract}
Thyroglobulin (TG) gene was known to be regulated fat cell growth and differentiation and the endothelial differentiation sphingolipid G-protein-coupled receptor 1 (EDG1) gene involves blood vessel formation and known to be affecting carcass traits in beef cattle. The aim of this study was to identify the single nucleotide polymorphisms (SNPs) in both TG and EDG1 genes and to analyze the association with carcass traits in Korean cattle (Hanwoo). The T354C SNP in TG gene located at the 3' flanking region and c.-312A $>$ G SNP located at 3'-UTR of EDG1 gene were used for genotyping the animals using PCR-RFLP method. Three genotypes were identified in T354C SNP in TG gene and only two AA and AG genotypes were observed for the c.-312A $>$ G SNP in EDG1 gene. The results indicated that T354C SNP in TG gene was not significantly associated with carcass traits. However, the c.-312A $>$ G SNP in EDG1 gene had significant effects on backfat thickness (BF) and yield index (YI). These results may provide valuable information for further candidate gene studies affecting carcass traits in Korean cattle and may use as marker assisted selection for improving the quality of meat in Hanwoo.
\end{abstract}

Key words : TG, EDG1, Carcass traits, Hanwoo

\section{Introduction}

Three traits, namely carcass weight (CW), longissimus muscle area (LMA) and marbling, are considered as important parameters in meat quality, especially in cattle in Korea (Cheong et al., 2006; Lee et al., 2008). Marbling is known as fat deposition in meat that significantly associated with juiciness and flavor

\footnotetext{
*Comesponding author: Tel: +82-42-821-5779

E-mail address: junheon@cnu.ac.kr
}

of meat (Shin et al., 2012). In Korea, high marbling score affects consumers' demands for high quality meat and also determines the cost differences of the meat.

Previously, several studies have been reported the single nucleotide polymorphisms (SNPs) in the candidate genes which was associated with carcass traits. This candidate gene approach is one of the effective tools to select the animals having desirable economic traits. For example, the polymorphism in MC4R gene influenced backfat thickness and marbling score, 
especially the SNP marker C1786T in Hanwoo (Seong et al., 2012). Also, the MYF5 was associated with increased meat tenderness and backfat thickness of beef cattle in China (Ujan et al., 2011). In addition, an SNP in GHR gene was associated the moisture and intramuscular fat in semi membranous muscle in beef samples (Reardon et al., 2010). Another report confirmed that the presence of SNPs in somatostatin (SST) gene was affected marbling and fat thickness, whereas adiponectin (ADIPOQ) gene affected both rib eye muscle area and fat thickness. These genes are located on BTA1 in cattle (Morsci et al., 2006).

Thyroglobulin gene (TG) produces the precursor for thyroid hormones which regulates metabolism and affects fat cell growth and differentiation. Also, this gene affects homeostasis of fat deports (Gan et al., 2008). This gene has been mapped on BTA14 in the previously known QTL region for carcass traits, especially marbling in Hanwoo (Shin and Chung, 2007). Hou et al. (2010) reported that 6 novel SNPs were found at the 3 'flanking region in TG gene. One of these SNPs, T354C SNP, was strongly associated with marbling scores. In addition, the endothelial differentiation sphingolipid G-protein-coupled receptor 1 (EDG1) gene, involved in blood vessel formation, is also known to be affecting carcass traits in beef cattle (Watanabe et al., 2010). This gene has been located in the Quantitative Trait Locus (QTL) region and mapped on BTA3 using radiation hybrid (RH) panel in Japanese Black Cattle (Yamada et al., 2006). Previous study reported by Yamada et al. (2009) showed that a SNP in the 5 untranslated region (UTR) of EDG1 gene may affect marbling score in Japanese Black Cattle. Both TG and EDG1 genes were located in QTL region. Thus, they were regarded as a positional functional candidate gene for carcass traits, especially for marbling scores.

Therefore, the aim of this study is to identify the polymorphisms in TG and EDG1 genes and to analyze their associations with carcass traits in Korean cattle, Hanwoo.

\section{Materials and Methods}

\section{Animals and data collection}

Seventy three longissimus thoracis Hanwoo beef samples were collected for genomic DNA extraction. The samples provided by the slaughter house with the help of the regional Hanwoo brand association called "Tobawoo". These cattle were all castrated males and reared under same feeding conditions including the fattening period and approximately 30 months old, these animals were slaughtered. Both carcass and meat quality data were provided by the Tobawoo. The meat parameter data including raw weight (RW), backfat thickness (BF), longissimus muscle (LM), carcass weight (CWT), yield index (YI), yield grade (YG), and marbling score (MS) were used in this study.

\section{The DNA extraction and genotyping}

For PCR amplification, two pairs of primers were designed for both thyroglobulin (TG) and EDG1 genes. The primers and restrictiction enzyme information are shown in Table 1.

Polymerase chain reaction was carried out in $20 \mu \mathrm{l}$ volume containing $50 \mathrm{ng} / \mathrm{\mu l}$ DNA genome, $0.8 \mu \mathrm{l}$ of each primer, $1.6 \mu \mathrm{l}$ dNTP, $2.0 \mu \mathrm{l}$ 10X reaction buffer,

Table 1. Primers and restriction enzyme information.

\begin{tabular}{llcccc}
\hline Gene & \multicolumn{1}{c}{ Primer } & PCR product size (bp) & GenBank acc. No. Restriction enzyme & Primer origin \\
\hline \multirow{2}{*}{ TG } & $\begin{array}{l}\text { F: 5'-TCCCAGAGTTAGCCTCCAAG-3' } \\
\text { R: 5'-GACCTCACCACCTCTCATTCA-3, }\end{array}$ & 709 & EU591737.1 & NlaIII & $\begin{array}{c}\text { Hou et al. } \\
(2011)\end{array}$ \\
\hline \multirow{2}{*}{ EDG1 } & $\begin{array}{l}\text { F: 5'-GTCTCAGCTGCACAGATCC-3' } \\
\text { R: 5'-GAAGACCTCCGGCCGCGAT-3' }\end{array}$ & 378 & NC_007301.5 & MscI & $\begin{array}{c}\text { Yamada et al. } \\
(2008)\end{array}$ \\
\hline
\end{tabular}


$0.2 \mu \mathrm{l}$ HS Taq Polymerase (GenetBio, Korea), and 12.6 $\mu$ distilated water. The PCR conditions were as follows: $94^{\circ} \mathrm{C}$ for 10 minutes, 34 cycles of $94^{\circ} \mathrm{C}$ for seconds, the annealing temperature were $55^{\circ} \mathrm{C}$ (TG) and $62^{\circ} \mathrm{C}$ (EDG1) for 30 seconds, and $72^{\circ} \mathrm{C}$ for 30 seconds, followed by a further 10 minutes final extention at $72^{\circ} \mathrm{C}$. Reaction was performed using either GeneAmp PCR system 2700 (Applied Biosystems, USA) or ${\mathrm{C} 1000^{\mathrm{TM}}}^{\mathrm{T}}$ Thermal Cycler (BioRad, USA). The PCR products were visualized by $1.5 \%$ standard agarose gels stained with ethidium bromide (GenetBio, Korea).

Each PCR fragment was purified using an AccuPrep ${ }^{\circledR}$ PCR Purification Kit (Bioneer, Korea). Purified PCR products were sequenced using the same primers for PCR reaction in an automated 3730 XL DNA Sequencer (Applied Biosystems, USA). The DNA sequence of TG and EDG1 genes were compared with reference sequences using the BioEdit program ver. 7.00 (Tom Hall, Ibis Therapeutics, California, USA). The sequence alignment was performed to determine the single nucleotide polymorphism (SNP) positions in the TG and EDG1 genes. The T354C SNP of TG gene was located in the 3-UTR (Fig. 1A), while the c. $-312 \mathrm{~A}>\mathrm{G}$ SNP of EDG1 was located in the 5-UTR region (Fig. 1B).
These SNPs have been confirmed with the electrophoregram results. For genotyping these SNPs, PCRrestriction fragment length polymorphism (RFLP) was applied. The restriction enzyme digestion was performed in $20 \mu \mathrm{l}$ reaction volumes with approximately $15 \mu \mathrm{l}$ of PCR products and 2 units of each restriction enzyme. The digested products were run on 3\% agarose gels.

\section{Statistical analysis}

Pearson's Chi-square test was used to verify the Hardy-Weinberg equilibrium status for the allele and genotype frequencies. The effects of TG and EDG1 genotypes on carcass traits were tested using ANOVA (Analysis of Variance) procedure in the SPSS version 17.0 program (SPSS, USA). The following model was used for the analysis the association of the genotype and carcass traits:

$\mathrm{Y}_{\mathrm{ij}}=\mu+\beta_{\mathrm{i}}+\varepsilon_{\mathrm{ij}}$

Where, $Y_{i j}$ is traits observed in the $i j^{\text {th }}$ animal, $\mu$ is the overall mean, $\beta_{i}$ is the $i^{\text {th }}$ genotype effect, and $\varepsilon_{i j}$ is a random error. In order to test the pairwise differences between the genotypes, Tukey's test was also performed.

(A)

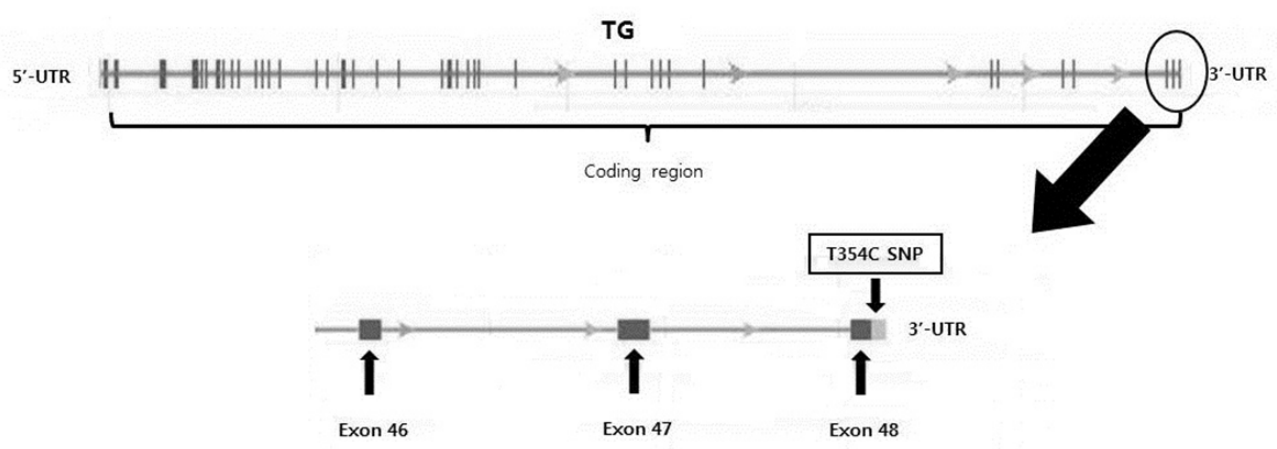

(B)

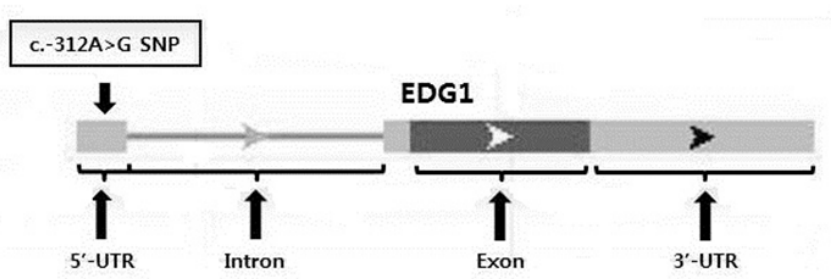

Fig. 1. The gene organizations for TG (A) and EDG1 (B) genes. 


\section{Results}

\section{Polymorphism of TG and EDGl in population}

Initially we sequenced the PCR product of both the TG and EDG1 genes and identified the SNPs. The T354C SNP of TG gene was used for PCR-RFLP genotyping of the animals. The $709 \mathrm{bp}$ of TG gene PCR product was digested into 282, 190, 112, 72, 31 and 22 bp fragments for the TT genotype using NlaIII restriction enzyme. On the other hand, the CC genotype gave $304,190,112,72$, and 31 bp restriction enzyme fragments (Fig. 2A). In case of EDG1 gene, c. $-312 \mathrm{~A}>\mathrm{G}$ SNP gave no restriction site of $378 \mathrm{bp}$ PCR product for GG genotype. However, for the AA genotype, the c. $-312 \mathrm{~A}>\mathrm{G}$ SNP was digested into $214 \mathrm{bp}$ and $164 \mathrm{bp}$ with $\mathrm{MSCI}$ restriction enzyme (Fig. 2B).

The genotype and alelle frequencies of TG and EDG1 genes are shown in Table 2. For the TG genes, all three genotypes (CC, TC, and TT) were observed. The TC genotype has the highest genotype frequency than other genotypes. The $\mathrm{C}$ allele frequency of TG gene was higher than the $\mathrm{T}$ allele frequency. In case of
EDG1 gene, only two genotypes, $\mathrm{AA}$ and $\mathrm{AG}$, were observed. The AA genotype was higher genotype frequency than AG genotype. The Pearson's Chi-square test was also used to verify the Hardy-Weinberg equilibrium status. The $X^{2}$ value of T354C SNP was lower than 3.84, indicating this SNP was in HardyWeinberg equilibrium (Table 2). However, $X^{2}$ value of c. $-312 \mathrm{~A}>\mathrm{G}$ SNP cannot be tested because only one GG genotype was observed.

\section{The association between identified} SNPs and carcass traits in Hanwoo

Seven carcass traits, namely raw weight (RW), backfat thickness (BF), longissimus muscle (LM), carcass weight (CW), yield index (YI), yield grade (YG), marbling score (MS), were used for association analysis of the SNPs in TG and EDG1 genes. The T354C SNP in TG gene was no association with the carcass traits. On the other hand, the c. $-312 \mathrm{~A}\rangle \mathrm{G}$ SNP in EDG1 gene gave significant results in backfat thickness $(\mathrm{BF})(\mathrm{P}<0.01)$. Animals having AA genotypes have higher BF than animals having AG genotypes. Also, this SNP was significantly associated with YI

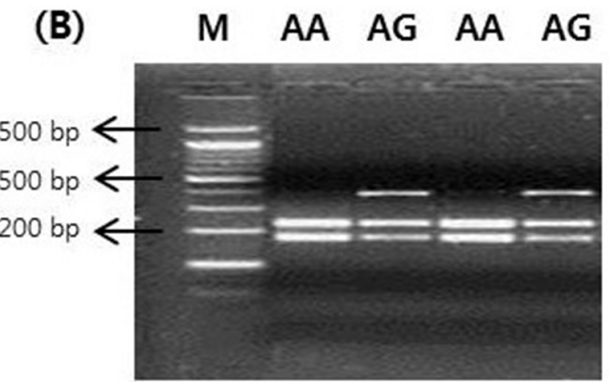

Fig. 2. PCR-RFLP results for the SNP T354C genotypes in TG gene (A) and c.-312A $>$ G genotypes in EDG1 gene (B).

Table 2. Genotype and alelle frequencies of TG and EDG1 SNPs in Hanwoo population.

\begin{tabular}{|c|c|c|c|c|c|c|}
\hline Gene & SNP & Genotype & Genotype frequency & Alelle & Alelle frequency & Chi-square $\left(X^{2}\right)$ test (P-Value) \\
\hline \multirow[t]{3}{*}{$T G$} & $\mathrm{~T} 354 \mathrm{C}$ & $\mathrm{CC}$ & 0.34 & $\mathrm{C}$ & 0.61 & $1.095(0.05)$ \\
\hline & & $\mathrm{TC}$ & 0.54 & $\mathrm{~T}$ & 0.39 & \\
\hline & & TT & 0.12 & & & \\
\hline \multirow[t]{3}{*}{$E D G 1$} & c. $-312 \mathrm{~A}>\mathrm{G}$ & AA & 0.81 & A & 0.90 & - \\
\hline & & AG & 0.19 & G & 0.10 & \\
\hline & & GG & 0 & & & \\
\hline
\end{tabular}


Jun Heon Lee / Identification of SNPs in TG and EDG1 genes and their relationships with carcass traits in Korean cattle (Hanwoo)

Table 3. Association analyses between identified SNPs and carcass traits in Hanwoo.

\begin{tabular}{|c|c|c|c|c|c|c|c|c|c|c|}
\hline \multirow{2}{*}{ Gene } & \multirow{2}{*}{ SNP } & \multirow{2}{*}{$\begin{array}{l}\text { Number of } \\
\text { animals }\end{array}$} & \multirow{2}{*}{ Genotype } & \multicolumn{7}{|c|}{ Traits $(\text { Mean } \pm \mathrm{SD})^{*}$} \\
\hline & & & & RW (kg) & $\mathrm{BF}(\mathrm{mm})$ & $\mathrm{LM}\left(\mathrm{cm}^{2}\right)$ & $\mathrm{CW}(\mathrm{kg})$ & YI (score) & YG (score) & MS (score) \\
\hline \multirow[t]{4}{*}{ TG } & $\mathrm{T} 354 \mathrm{C}$ & 73 & TT & $656.11 \pm 35.35$ & $10.44 \pm 2.60$ & $86.56 \pm 3.84$ & $403.33 \pm 24.16$ & $66.45 \pm 1.81$ & $1.78 \pm 0.44$ & $6.63 \pm 1.33$ \\
\hline & & & $\mathrm{TC}$ & $679.93 \pm 49.03$ & $10.18 \pm 3.28$ & $90.40 \pm 9.48$ & $412.38 \pm 30.91$ & $66.91 \pm 2.74$ & $1.53 \pm 0.51$ & $6.93 \pm 0.99$ \\
\hline & & & $\mathrm{CC}$ & $670.17 \pm 43.54$ & $9.71 \pm 4.08$ & $89.83 \pm 10.04$ & $408.25 \pm 33.60$ & $67.22 \pm 2.63$ & $1.54 \pm 0.51$ & $6.48 \pm 1.19$ \\
\hline & & & $P$-value & 0.338 & 0.822 & 0.530 & 0.699 & 0.744 & 0.385 & 0.283 \\
\hline \multirow[t]{3}{*}{ EDG1 } & c. $-312 A>G$ & 73 & AA & $672.71 \pm 48.15$ & $10.63 \pm 3.43$ & $90.14 \pm 8.67$ & $410.47 \pm 32.95$ & $66.63 \pm 2.53$ & $1.61 \pm 0.49$ & $6.82 \pm 1.09$ \\
\hline & & & $\mathrm{AG}$ & $685.79 \pm 41.26$ & $7.79 \pm 2.99$ & $90.07 \pm 11.03$ & $410.71 \pm 23.36$ & $68.40 \pm 2.58$ & $1.36 \pm 0.50$ & $6.37 \pm 1.11$ \\
\hline & & & $P$-value & 0.352 & $0.006^{* *}$ & 0.981 & 0.98 & $0.023^{* *}$ & 0.089 & 0.178 \\
\hline
\end{tabular}

"RW: Raw Weight, BF: backfat thickness, LM: longissimus muscle area, CW: carcass weight, YI: yield index, YG: yield grade, MS: marbling score.

$(\mathrm{P}<0.05)$. Animals having AG genotype have higher YI than animals having AA genotype (Table 3).

\section{Discussion}

Both T354C SNP of TG gene and c. $-312 \mathrm{~A}>\mathrm{G}$ SNP of EDG1 gene were detected by direct sequencing of the PCR products from a number of samples and PCRRFLP was applied for the genotyping of all the samples. Previous study reported that these SNPs were strongly associated with carcass quality traits in beef cattle, especially for the marbling scores (Hou et al., 2011; Yamada et al., 2008).

The homozygous CC animals in SNP position T354C was higher than TT animals for TG gene. The $\mathrm{C}$ allele frequency was higher than $\mathrm{T}$ allele in the Hanwoo samples in this study. These results suggested that Hanwoo population may have different allele frequency, compared with the previous study reported by Hou et al. (2011). Previous study reported that TG gene, located on BTA14, was considered as functional candidate gene for fat deposition in beef (Rincker et al., 2006). This gene have been mapped as a candidate gene which effects on lipid metabolism (Moore et al., 2003). Also, previous study indicated that the T354C SNP of TG gene was significantly associated with marbling score (Hou et al., 2011). However, in a case of this study, the T354C SNP of TG gene was not associated with marbling score in Hanwoo. Similar results were found in crossbred cattle in Ireland, the SNPs in DGAT1, TG and FABP4 had no association with intramuscular fat (IMF) level in crossbreed BoS taurus beef cattle (Pannier et al., 2010).

In this study, the c. $-312 \mathrm{~A}>\mathrm{G}$ SNP in EDG1 gene was significantly associated with backfat thickness (BF) and AA genotype was favorable for this trait. Backfat thickness plays important role in beef carcass preservation after slaughter and determines organoleptic characteristics for consumer (Veneroni-Gouveia et al., 2011). This SNP will be valuable as a marker to produce animals which have high BF. However, the c. $-312 \mathrm{~A}>\mathrm{G}$ SNP gave no association with marbling score. In contrast, study in Japanese Black Cattle, the same SNP c. $-312 \mathrm{~A}>\mathrm{G}$ in EDG1 have no association with $\mathrm{BF}$, but it was significantly associated with marbling score (Yamada et al., 2009; Sukegawa et al., 2010). Other SNP in EDG1 gene, g.1471620G>T SNP, was strongly associated with high marbling score. Previous study indicated the $\mathrm{T}$ allele was favorable for high marbling score in Japanese Black Cattle (Watanabe et al., 2010). The discrepancy between Hanwoo and Japanese Black cattle indicated that the breed defferences may affect for the variation in these traits. The c. $-312 \mathrm{~A}>\mathrm{G}$ SNP was also significantly associated with yield index (YI), where AG animals were favorable for YI $(p<0.05)$. Yield index or meat yield index becomes one of important economic traits in beef cattle (Lee et al., 2011), especially in Hanwoo 
(Li et al., 2010). Therefore, this SNP may be used as a valuable marker for selecting Hanwoo with high yield index.

In conclusion, this study identified the novel c. $-312 \mathrm{~A}>\mathrm{G}$ SNP in EDG1 gene and their association with backfat thickness (BF) and yield index (YI) in Hanwoo. However, for the practical application, larger scale and precise analyses are needed to confirm the marker effects.

\section{Acknowledgements}

This work was partially supported by awards from the AGENDA project (Grant no. PJ907008062012) and Molecular Breeding program (PJ0081882012) of Next Generation BioGreen21 project in the National Institute of Animal Science, Rural Development Administration (RDA).

\section{References}

Cheong HS, Yoon DH, Kim LH, Park BL, Choi YH, Chung ER, Cho YM, Park EW, Cheong IC, Oh SJ, Yi SG, Park T, Shin HD. 2006. Growth hormone-releasing hormone (GHRH) polymorphisms associated with carcass traits of meat in Korean cattle. BMC Genetics 7: 35-40.

Gan QF, Zhang LP, Li JY, Hou GY, Li HD, Gao X, Ren HY, Chen JB, Xu SZ. 2008. Association analysis of thyroglobulin gene variants with carcass and meat quality traits in beef cattle. Journal of Applied Genetics 49: 251-255.

Hou GY, Yuan ZR, Ahou HL, Zhang LP, Li JY, Gao X, Wang DJ, Gao HJ, Xu SZ. 2011. Association of thyroglobulin gene variants with carcass and meat quality traits in beef cattle. Molecular Biology Reports 38: 4705-4708.

Lee JJ, Choi SD, Dang CG, Kang SN, Kim NS. 2011. The effect of carcass traits on economic values in Hanwoo. Korean Journal for Food Science of Animal Resources 31: 603-608.

Lee SH, Cho YM, Kim BS, Kim NK, Choy YH, Kim KH, Yoon D, Im SK, Oh SJ, Park EW. 2008. Identification of marbling-related candidate genes in M. longissimus dorsi of high- and low marbled Hanwoo (Korean Native Cattle) steers. BMB Reports 41: 846-851.

Li SG, Yang YX, Rhee YJ, Jang WJ, Ha JJ, Lee SK, Song YH. 2010. Growth, behavior, and carcass traits of fattening Hanwoo (Korean Native Cattle) steers managed in different group sizes. Asian-Australasian Journal of Animal Science
23: 952-959.

Moore SS, Li C, Basarab J, Snelling WM, Kneeland J, Murdoch B, Hansen C, Benkel B. 2003. Fine mapping of quantitative trait loci and assessment of positional candidate genes for backfat on bovine chromosome 14 in a commercial line of Bos taurus. Journal of Animal Science 81: 1919-1925.

Morsci NS, Schnabel RD, Taylor JF, 2006. Association analysis of Adiponectin and Somatostatin polymorphisms on BTA1 with growth and carcass traits in Angus cattle. Animal Genetics 37: 554-562.

Pannier L, Mullen AM, Hamill RM, Stapleton PC, Sweeney T. 2010. Association analysis of single nucleotide polymorphisms in DGAT1, TG and FABP4 genes and intramuscular fat in crossbred Bos taurus cattle. Meat Science 85: $515-518$.

Reardon W, Mullen AM, Sweeney T, Hamill RM. 2010. Association of polymorphisms in candidate genes with colour, water-holding capacity, and composition traits in bovine M. Longissimus and M. Semimembranosus. Meat Science 86: 270-275.

Rincker CB, Pyatt NA, Berger LL, Faulkner DB. 2006. Relationship among gene STAR marbling marker, intramuscular fat deposition, and expected progeny differences in early weaned simmental steers. Journal of Animal Science 84: 686-693.

Seong J, Suh DS, Park KD, Lee HK, Kong HS. 2012. Identification and analysis of MC4R polymorphisms and their association with economic traits of Korean Cattle (Hanwoo). Molecular Biology Reports 39: 3597-3601.

Shin SC, Chung ER. 2007. Association of SNP marker in the Thyroglobulin gene with carcass and meat quality traits in Korean Cattle. Asian-Australasian Journal of Animal Science 20: 172-177.

Shin SC, Heo JP, Chung ER. 2012. Genetic variants of the FABP4 gene are associated with marbling scores and meat quality grades in Hanwoo (Korean cattle). Molecular Biology Reports 39: 5323-5330.

Ujan JA, Zan LS, Ujan SA, Adoligbe C, Wang HB. 2011. Back fat thickness and meat tenderness are associated with a 526 $\mathrm{T}>\mathrm{A}$ mutation in the exon 1 promoter region of the MYF-5 gene in Chinese Bos taurus. Genetics and Molecular Research 10: 3070-3079.

Veneroni-Gouveia G, Meirelles SL, Grossi DA, Santiago AC, Sonstegard TS, Yamagishi ME, Matukumalli LK, Coutinho LL, Alencar MM, Oliveira HN, Regitano LC. 2011. Wholegenome analysis for backfat thickness in a tropically adapted, composite cattle breed from Brazil. Animal Genetics doi:10. 1111/j.1365-2052.2011.02286.x

Yamada T, Taniguchi Y, Nishimura S, Yoshioka S, Takasuga A, Sugimoto Y, Sasaki Y. 2006. Radiation hybrid mapping of genes showing intramuscular fat deposition-associated expression changes in bovine musculus longissimus muscle. Animal Genetics 37: 184-185. 
Yamada T, Itoh M, Nishimura S, Taniguchi Y, Miyake T, Sasaki S, Yoshioka S, Fujita T, Shiga K, Morita M, Sasaki Y. 2009. Association of single nucleotide polymorphisms in the Endothelial differentiation sphingolipid g-protein-coupled receptor 1 gene with marbling in japanese black beef cattle. Animal Genetics 40: 209-216.
Watanabe N, Yamada T, Yoshioka S, Itoh M, Satoh Y, Furuta M, Komatsu S, Sumio Y, Fujita T, Sasaki Y. 2010. The T allele at the g.1471620 G>T in the EDG1 gene associated with high marbling in Japanese Black Cattle is at a low frequency in breeds not selected for marbling. Animal Science Journal 81: 142-144. 